\title{
Family empowerment in protecting children from the influence of addictive substances during COVID-19 pandemic in village of Bandar Labuhan district of Tanjung Morawa regency of Deli Serdang
}

\author{
Eva Syahfitri Nasution ${ }^{1 *}$, Ritha F Dalimunthe ${ }^{2}$, Pujiati $^{3}$, Ameilia Zuliyanti Siregar ${ }^{4}$, Arif \\ Qaedi Hutagalung ${ }^{2}$ \\ ${ }^{1}$ Criminal Law Department, Faculty of Law, Universitas Sumatera Utara, Medan, Indonesia \\ ${ }^{2}$ Department of Management, Economy and Business Faculty, Universitas Sumatera Utara, \\ Indonesia \\ ${ }^{3}$ Faculty of Cultural Studies Universitas Sumatera Utara, Medan, Indonesia \\ ${ }^{4}$ Department of Agronomy, Faculty of Agriculture, Universitas Sumatera Utara, Medan, \\ Indonesia \\ *Email: evanasutionfhusu@usu.ac.id
}

\begin{abstract}
The Covid-19 pandemic that occurred shows the increasingly important role of families in caring and educating children. Amount of children spend time at home because studying online, it means that they spend a lot of time outside with friends. This allows children to consume addictive substances. From the initial survey conducted in village of Bandar Labuhan district of Tanjung Morawa regency of Deli Serdang, it was found that children secretly consume addictive substances which are harmful to their own health, such as smoking. The method of implementing community service activities is carried out in three stages, including the stages of preparation, implementation and guidance. Addictive substances are substances that cause addiction or dependence and are harmful. From the results of the dedication, it was found that most of the abuse of addictive substances in children in village of Bandar Labuhan district of Tanjung Morawa was cigarettes, glue and gasoline. Most of the factors that influence addictive substance abuse in children are curiosity. Empowerment of families in protecting children from addictive substance abuse is very necessary for children avoid addictive substances. This is in accordance with the mandate of Law No. 35 of 2014 concerning Amendments to Law No. 23 of 2002 concerning Child Protection and North Sumatra Regional Regulation No. 1 of 2019 concerning Facilitation for the Prevention of Abuse of Narcotics, Psychotropics and Other Addictive Substances.
\end{abstract}

\section{Keyword: Family Empowerment, Protecting Children, Addictive Substances}

\begin{abstract}
Abstrak
Pandemi Covid-19 yang terjadi menunjukkan semakin pentingnya peran keluarga dalam mengasuh dan mendidik anak. Banyak anak menghabiskan waktu di rumah karena belajar daring menjadikan anak banyak menghabiskan waktu di luar rumah bersama teman. Hal tersebut memungkinkan anak untuk mengkonsumsi zat adiktif. Dari survey awal yang dilakukan di Desa Bandar Labuhan Kecamatan Tanjung Morawa Kabupaten Deli Serdang didapatkan informasi bahwa anak secara sembunyi mengkonsumsi zat adiktif yang pada hakikatnya berbahaya bagi kesehatan anak itu sendiri misalnya merokok. Metode pelaksanaan kegiatan pengabdian kepada masyarakat yang dilaksanakan dilakukan dalam tiga tahapan, meliputi tahap persiapan, pelaksanaan dan pembimbingan. zat adiktif adalah bahan yang menyebabkan adiksi atau ketergantungan dan membahayakan. Dari hasil pengabdian di dapat bahwa sebagian besar penyalahgunaan zat adiktif pada anak di Desa Bandar Labuhan Kecamatan Tanjung Morawa adalah rokok, lem dan bensin. Faktor yang mempengaruhi penyalahgunaan zat adiktif pada anak sebagian besar adalah rasa ingin tahu. Pemberdayaan keluarga dalam perlindungan anak dari penyalahgunaan zat adiktif sangat diperlukan agar anak terhindar dari zat adiktif. Hal tersebut sesuai amanat Undang-Undang No. 35 Tahun 2014 tentang Perubahan Atas Undang-Undang No. 23 Tahun 2002 tentang Perlindungan Anak dan Peraturan Daerah Sumatera Utara No. 1 Tahun 2019 tentang Fasilitasi Pencegahan Penyalahgunaan Narkotika, Psikotropika dan Zat Adiktif Lainnya.
\end{abstract}

Kata Kunci: Pemberdayaan Keluarga, Perlindungan Anak, Zat Adiktif 


\section{PENDAHULUAN (INTRODUCTION)}

Peristiwa pandemi Covid-19 yang terjadi dihampir seluruh dunia ini, menunjukkan semakin pentingnya peran keluarga dalam mengasuh, merawat dan juga mendidik anak. Dalam kondisi saat ini, anak banyak menghabiskan waktu di rumah karena kegiatan belajar mengajar disekolah diganti menjadi kegiatan belajar mengajar secara daring. Peristiwa ini mengembalikan fungsi awal keluarga sebagai pusat segala kegiatan, tempat terjadinya pendidikan yang utama untuk anak. Setiap orang tua pasti menginginkan anaknya selalu dalam keadaan sehat, apalagi dengan kondisi saat ini yaitu pada masa pandemi COVID-19 tentu saja orang tua menjadi semakin khawatir akan hal itu. Salah satu yang dapat di lakukan orang tua adalah mengingatkan anak nya untuk selalu menerapkan pola hidup sehat dan bersih agar terhindar dari berbagai penyakit dan dengan mengajarkan anak untuk mengikuti protokol kesehatan.

Pemberdayaan Keluarga sebagai unit sosial terkecil dalam masyarakat mempunyai peranan penting dalam menghidari penyalahgunaan zat adiktif. Peran orang tua dan kondisi keluarga mempengaruhi perkembangan kepribadian anak. Apakah kepribadian anak akan rentan atau tidak terhadap penyalahgunaan zat adiktif tergantung dari cara pendidikan orang tua (ayah dan ibu) dan suasana rumah tangga kondusif atau tidak. Orang tua dan keluarga dapat menyebabkan seseorang tergolong untuk menyalahgunakan narkotika, apabila kondisi orang tua atau keluarga tidak mampu menghayati perkembangan dan aspirasi anaknya, serta lemah dalam memberikan pengarahan dan pengawasan.

Dilihat dari data yang ada, korban penyalahgunaan zat adiktif di Indonesia tidak terbatas pada masyarakat mampu, akan tetapi sudah merambah ke kalangan masyarakat ekonomi rendah (Harbia, Muhammad Multazam, Andi Asrina, Window of Health: Jurnal Kesehatan, Vol. 1 No. 3, Juli 2018, hlm. 204-2016). Dari segi usia, pengguna zat adiktif bukan hanya di usia yang tergolong dewasa melainkan juga dikonsumsi anak di bawah umur. Panyalahgunaan zat adiktif di kalangan usia anak memberikan suatu kekhawatiran kepada segenap lapisan masyarakat mengingat bahaya yang ditimbulkan pada generasi yang akan menjadi penerus bangsa.

Pada saat survey awal di desa mitra yakni di Desa Bandar Labuhan Kecamatan Tanjung Morawa Kabupaten Deli Serdang serta Instansi Pemerintahan Kecamatan Tanjung Morawa Kabupaten Deli Serdang didapat beberapa informasi antara lain bahwa kenyataannya tidak jarang anak secara sembunyi-sembunyi melakukan kegiatan mengkonsumsi zat adiktif yang pada hakikatnya berbahaya bagi kesehatan anak itu sendiri misalnya merokok. Banyak orang yang telah mengetahui secara umum bahwa penggunaan tembakau berbahaya bagi kesehatan mereka, namun banyak aspek dari tembakau yang belum cukup dijelaskan, sehingga tidak dapat dimengerti dengan baik oleh pengguna tembakau. Akibatnya perokok cenderung menyepelekan resiko kesehatan dari penggunaan tembakau terhadap diri mereka sendiri maupun orang-orang yang terpapar zatnya (Afdol Rahmadi, Yuniar Lestari, Yenita, Jurnal Kesehatan Andalas, Vol 2 No. 1 2013, hlm. 2528).
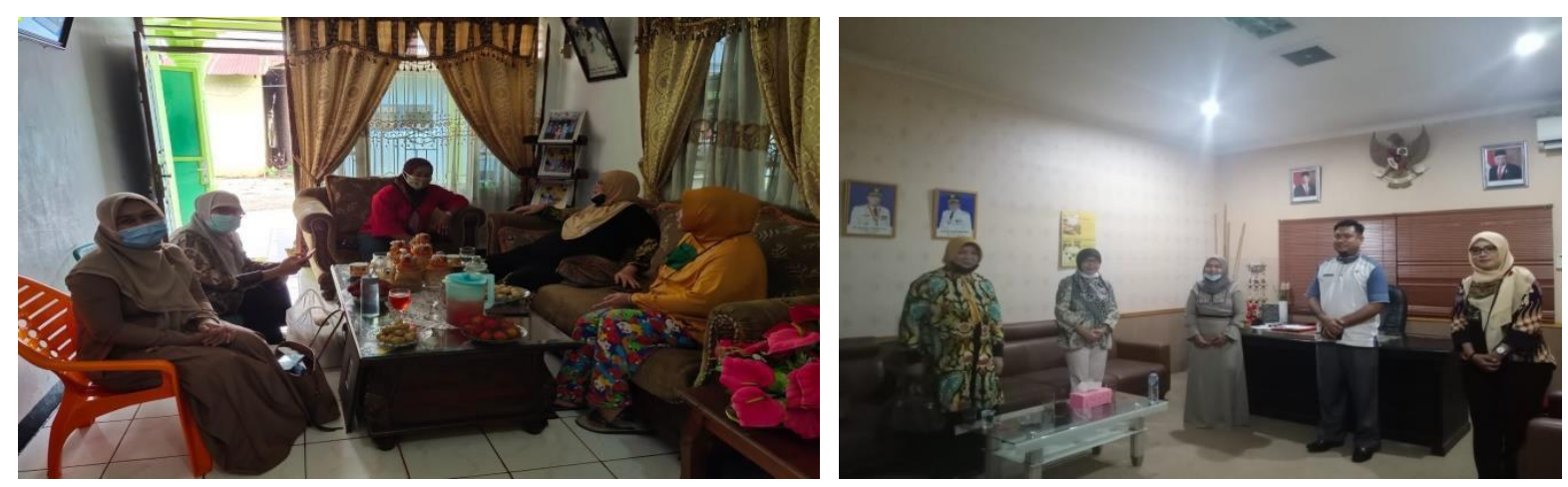

Gambar 1.1. Kunjungan untuk Survey Awal ke Desa Bandar Labuhan (Kiri) dan Kantor Camat Tanjung Morawa (Kanan) 
Korban penyalahgunaan zat adiktif di Indonesia tidak terbatas pada masyarakat mampu, akan tetapi sudah merambah ke kalangan masyarakat ekonomi rendah (Harbia, Muhammad Multazam, Andi Asrina, Window of Health: Jurnal Kesehatan, Vol. 1 No. 3, Juli 2018, hlm. 2042016). Padahal, Pasal 59 UU No. 35 Tahun 2014 tentang Perubahan Atas UU No. 23 Tahun 2002 tentang Perlindungan Anak secara tegas telah menempatkan anak harus dilindungi dari penyalahgunaan narkotika, alkohol, psikotropika, dan zat adiktif lainnya.

Provinsi Sumatera Utara telah mengeluarkan sebuah Peraturan Daerah Sumatera Utara No. 1 Tahun 2019 tentang Fasilitasi Pencegahan Penyalahgunaan Narkotika, Psikotropika dan Zat Adiktif Lainnya. Peraturan Daerah yang diundangkan pada tanggal 14 Januari Tahun 2019 ini didasari guna melindungi masyarakat khususnya masyarakat Sumatera Utara termasuk masyarakat yang ada di Desa Bandar Labuhan Kecamatan Tanjung Morawa Kabupaten Deli Serdang dari bahaya narkotika, psikotropika dan zat adiktif lainnya yang didalamnya terdapat fasilitasi pencegahan berbasis keluarga. Selain itu, terdapat upaya perlindungan khusus bagi anak yang menjadi penyalahguna atau korban penyalahgunaan zat adiktif. Mengingat banyak orang yang belum sadar akan bahaya merokok yang merupakan salah satu dari zat adiktif yang berbahaya khususnya bagi anak. Sehingga perlu adanya sosialisasi yang dilaksanakan untuk untuk menyadarkan keluarga dan masyarakat dalam melakukan perlindungan anak dari zat adiktif khususnya di masa pandemi Covid 19.

\section{METODE PELAKSANAAN (METHODS)}

Kegiatan pengabdian kepada masyarakat ini akan dilaksanakan di Desa Bandar Labuhan Kecamatan Tanjung Morawa Kabupaten Deli Serdang. Untuk mendukung kegiatan ini, perlu diselesaikan dan disinergikan bersama antara mitra dengan sivitas akademika. Kegiatan dilakukan dalam tiga tahapan, meliputi tahap persiapan, tahap pelaksanaan dan tahap pembimbingan. Strategi pencapaian target dan luaran disajikan pada Gambar 1.

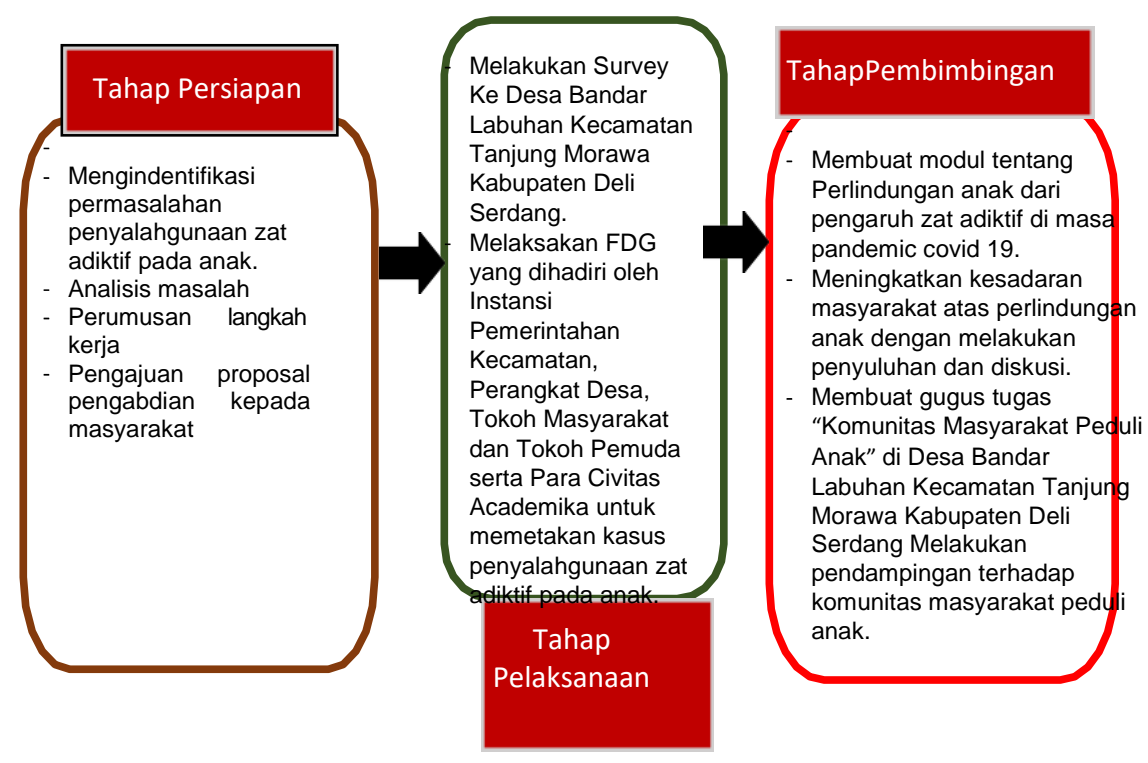

Gambar 2.1. Diagram Strategi Pemecahan Masalah Mitra 
Untuk mendukung strategi pemecahan masalah mitra ini, maka ada beberapa hal yang akan dilakukan antara lain:

1. Tahapan persiapan

Pada tahapan ini, tim pengabdian masyarakat akan melihat Melihat permasalahan penyalahgunaan zat adiktif pada anak di Bandar Labuhan Kecamatan Tanjung Morawa Kabupaten Deli Serdang. Merencanakan pembentukan gugus tugas bersama seluruh lapisan masyarakat untuk mewujudkan masyarakat peduli anak untuk mencegah pengaruh negatif dari zat adiktif. Kemudian, melakukan analisis masalah, perumusan langkah kerja, pengajuan proposal pengabdian kepada masyarakat.

2. Tahapan pelaksanaan dan pembimbingan

Pada tahap ini di lakukan survey ke Desa Bandar Labuhan Kecamatan Tanjung Morawa Kabupaten Deli Serdang. Kemudian melaksakan FDG yang dihadiri oleh Instansi Pemerintahan Kecamatan, Perangkat Desa, Tokoh Masyarakat dan Karang Taruna serta Para Civitas Academika untuk memetakan kasus penyalahgunaan zat adiktif pada anak. Selanjutnya dilakukan pembuatan modul untuk meningkatkan pemberdayaan keluarga dalam perlindungan anak terhadap penyalahgunaan zat adiktif di masa pandemi Covid 19 di Desa Bandar Labuhan Kecamatan Tanjung Morawa Kabupaten Deli Serdang. Kemudian melakukan peningkatan kesadaran masyarakat atas perlindungan anak dengan melakukan penyuluhan dan diskusi serta membuat gugus tugas komunitas masyarakat peduli anak dilanjutkan dengan melakukan pendampingan terhadap komunitas tersebut.

\section{HASIL DAN PEMBAHASAN (RESULT AND DISCUSSION)}

\subsection{Pengertian Zat Adiktif}

Menurut Peraturan Pemerintah Republik Indonesia Nomor 109 Tahun 2012 disebutkan bahwa zat adiktif adalah bahan yang menyebabkan adiksi atau ketergantungan dan membahayakan kesehatan yang ditandai dengan berubahnya perilaku, kognitif dan fenomena fisiologis, keinginan kuat untuk mengkonsumsi bahan tersebut, kesulitan dalam mengendalikan penggunaannya, memberi prioritas pada bahan tersebut dari pada kegiatan lain, meningkatnya toleransi dan dapat menyebabkan keadaan gejala putus obat. Kelompok zat adiktif ini meliputi alkohol, nikotin, obat hisap, pelarut dan lem fox (Ratna Umi Nurlila dan Jumarddin La Fua, Jurnal AL-Ta'dib, Vol 10 No. 1 JanuariJuni 2017, hlm. 70-90).

\subsection{Kondisi Penyalahgunaan Zat Adiktif pada Anak di Indonesia}

Berdasarkan data Badan Pusat Statistik Tahun 2019, diketahui bahwa 30,1\% penduduk Indonesia adalah anak. Sebagai Investasi bangsa anak harus dijaga dari hal-hal yang merugikan fisik dan psikisnya. Namun, hal yang sangat mengejutkan adalah berdasarkan sumber Kementerian Kesehatan Republik Indonesia, proporsi merokok pada anak usia 10-14 Tahun adalah untuk perokok setiap hari berjumlah $0,70 \%$, perokok kadang-kadang berjumlah $1,40 \%$, mantan perokok $2 \%$ dan perokok pasif sebanyak $95,90 \%$. Sedangkan menurut survey Global Youth Tobacco pada tahun 2014, perokok remaja usia 13-15 tahun (43,2\%) mulai merokok di usia 12-13 tahun, dan sebanyak 11,4\% mulai merokok di usia 14-15 tahun. Kemudian, keinginan untuk mencoba rokok juga dilakukan pada usia sangat dini, yakni sebanyak $8,9 \%$ mulai merokok saat usia $\leq 7$ tahun.

Selain rokok, peningkatan konsumsi alkohol pada anak di Indonesia juga meningkat tajam. Perilaku konsumsi minum alkohol saat ini merupakan permasalahan yang cukup berkembang, bahkan mengalami peningkatan dari tahun ke tahun. Berdasarkan data Riset Kesehatan Dasar Tahun 200, prevalensi konsumsi alkohol di Indonesia dari 258.366 sampel rumah tangga pada 1 tahun terakhir adalah $8,8 \%$ laki-laki dan $0,7 \%$ perempuan. Prevalensi peminum alkohol mulai 
Eva Syahfitri Nasution et.al. Family empowerment in protecting children

tinggi pada umur antara 15-24 tahun yaitu sebesar 5,5\% (Solina, Triana Arisdiani, Yuni Puji Widyastuti, Jurnal Keperawatan Jiwa, Vol. 6 No. 1, Mei 2018, hlm. 36-45).

\subsection{Perlindungan Anak Terhadap Zat Adiktif di Indonesia}

Anak adalah amanah sekaligus karunia Tuhan Yang Maha Esa yang senantiasa harus dijaga karena di dalam dirinya melekat harkat, martabat dan hak-hak sebagai manusia yang harus dijunjung tinggi. Hak asasi anak merupakan bagian dari hak asasi manusia yang termuat di dalam UndangUndang Dasar 1945 dan Konvensi Perserikatan Bangsa-Bangsa tentang Hak Anak. Dari sisi kehidupan berbangsa dan bernegara, anak adalah masa depan bangsa dan generasi penerus cita-cita bangsa, sehingga setiap anak berhak atas kelangsungan hidup, tumbuh dan berkembang, berpartisipasi serta berhak atas perlindungan dari tindakan kekerasan dan diskriminasi serta hak sipil dan kebebasan (Penjelasan atas UU No. 35 Tahun 2014 tentang Perubahan Atas UU No. 23 Tahun 2002 tentang Perlindungan Anak, 2010, hlm. 35).

Sebagai makhluk Tuhan Yang Maha Esa, anak memiliki hak-hak sesuai dengan kemuliaan harkat dan martabatnya yang dilindungi oleh peraturan perundang-undangan. Anak perlu mendapatkan kesempatan seluas-luasnya untuk tumbuh dan berkembang secara optimal. Anak sebagai bagian dari generasi muda seharusnya perlu dibina secara terus menerus demi kelangsungan hidup, pertumbuhan fisik, mental dan sosial serta perlindungan dari segala kemungkinan yang akan membahayakan mereka dan bangsa di masa depan (C.S.T. Kansil, Engelien R. Palandeng, dan Altje Agustin Musa, 2009, hlm. 141).

Begitu kompleks permasalah penggunaan zat adiktif oleh anak di Indonesia. Padahal peraturan mengenai perlindungan anak terhadap zat adiktif telah diatur secara jelas di Indonesia di dalam Undang-Undang No. 35 Tahun 2014 tentang Perubahan Atas Undang-Undang No. 23 Tahun 2002 tentang Perlindungan Anak.

Pemerintah dan lembaga negara lainnya berkewajiban dan bertanggung jawab untuk memberikan perlindungan khusus kepada anak dalam situasi darurat, anak yang berhadapan dengan hukum, anak dari kelompok minoritas dan terisolasi, anak tereksploitasi secara ekonomi dan/atau seksual, anak yang diperdagangkan, anak yang menjadi korban penyalahgunaan narkotika, alkohol, psikotropika, dan zat adiktif lainnya (napza), anak korban penculikan, penjualan dan perdagangan, anak korban kekerasan baik fisik dan/atau mental, anak yang menyandang cacat, dan anak korban perlakuan salah dan penelantaran.

\subsection{Kondisi Penyalahgunaan Zat Adiktif pada Anak di Desa Bandar Labuhan Kecamatan Tanjung Morawa}

Data yang didapat pada saat survey awal dan penyuluhan menunjukkan bahwa sebagian besar penyalahgunaan zat adiktif pada anak dan remaja di Desa Bandar Labuhan Kecamatan Tanjung Morawa antara lain:
a. Rokok;
b. Lem; dan
c. Bensin.

Sebagian besar anak dan remaja biasanya mengkonsumsi zat adiktif ini secara sembunyisembunyi, selebihnya dilakukan secara terbuka. Terlebih lagi, anak memiliki waktu yang panjang untuk bermain karena belajar secara daring disebabkan Pandemi Covid 19 saat ini. Dari hasil data yang diperoleh di lapangan didapatkan bahwa hal yang pernah dilakukan saat mengetahui anak yang melakukan penyalahgunaan zat adiktif tersebut adalah sebagai berikut:

a. Memberikan teguran agar anak tidak menyalahgunakan zat adiktif;

b. Menasihati dan memberi informasi bahwa merokok berbahaya bagi kesehatan;

c. Memberikan kata-kata sindiran seperti "Ih, masih kecil merokok";

d. Melarang anak untuk merokok;

e. Memberi penjelasan bahwa merokok itu mengandung zat berbahaya; 
f. Menegur secara langsung atau melaporkan kepada orang tua/wali anak yang bersangkutan; dan

g. Bertanya mengapa anak tersebut merokok dan menghimbau bahwa perbuatan tersebut adalah perbuatan yang tidak baik.

Disamping itu, beberapa jawaban responden saat mereka mengetahui anak yang melakukan penyalahgunaan zat adiktif antara lain:

a. Bersikap cuek apabila anak tersebut bukan merupakan anggota keluarga, tetapi jika anak tersebut adalah keluarga maka akan ditegur; dan

b. Tidak akan menegur anak tersebut karena takut anak tersebut akan marah dan berbuat kasar.

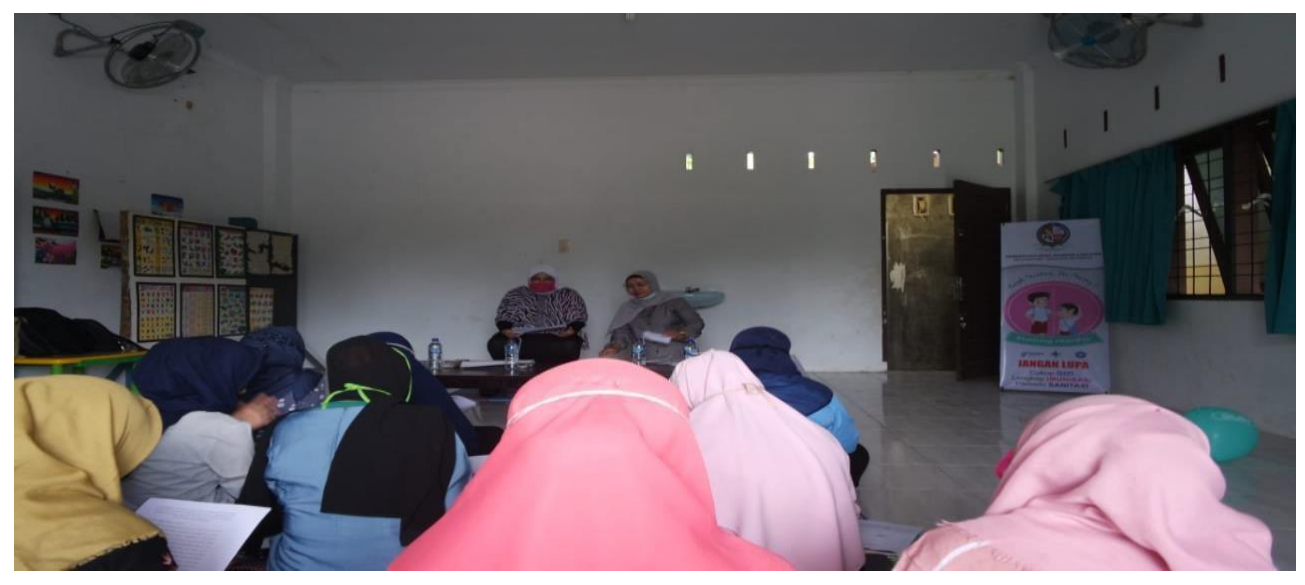

Gambar 3.1. Pelaksanaan Pengabdian Kepada Masyarakat di Desa Bandar Labuhan Kecamatan Tanjung Morawa

\subsection{Faktor-Faktor yang Menyebabkan Penyalahgunaan Zat Adiktif pada Anak di Desa Bandar Labuhan Kecamatan Tanjung Morawa dan Upaya Pencegahan yang Dapat Dilakukan oleh Keluarga di Masa Pandemi Covid 19.}

Pada dasarnya telah dijelaskan sebelumnya ada banyak faktor yang mempengaruhi anak dalam hal penyalahgunaan zat adiktif yakni mulai dari keinginan sendiri, rasa ingin tahu, cobacoba dan melihat teman-temannya, serta merokok dianggap memudahkan pergaulan. Hal tersebut juga terjadi pada anak di Desa Bandar Labuhan Kecamatan Tanjung Morawa. Dari data primer yang didapat dari responden pengabdian maka diketahui bahwa terdapat beberapa faktor yang menyebabkan anak menyalahgunakan zat adiktif di Desa Bandar Labuhan Kecamatan Tanjung Morawa, antara lain:

a. Pergaulan dengan teman sebaya yang merupakan perokok atau pengguna zat adiktif;

b. Ajang coba-coba;

c. Rasa penasaran yang tinggi;

d. Kurang mendapat perhatian dari orang tua;

e. Kurangnya keterbukaan dan minimnya informasi tentang zat adiktif di dalam keluarga; dan

f. Lingkungan yang kurang peduli terhadap anak;

Dari faktor- faktor tersebut dapat diketahui bahwa pergaulan/pertemanan dengan teman yang merupakan pecandu dari zat adiktif merupakan faktor yang paling berpengaruh bagi anak untuk menyalahgunakan zat adiktif. Dari faktor-faktor tersebut dapat dilihat pula pada dasarnya keluarga sangat memegang peranan penting untuk mencegah terjadi penyalahgunaan zat adiktif pada anak.

Upaya pencegahan yang seharusnya dilakukan oleh keluarga dan masyarakat untuk mencegah terjadinya penyalahgunaan zat adiktif oleh anak antara lain:

a. Memberikan pengarahan dan edukasi sejak dini tentang bahaya zat adiktif; 
b. Pengawasan dari orang tua dan masyarakat;

c. Membiasakan pola hidup sehat di dalam keluarga;

d. Memberi perhatian kepada anak;

Zat adiktif yang paling banyak di konsumsi oleh anak di Desa Bandar Labuhan adalah rokok. Untuk mengatasi permasalahan bagi perokok, maka ada beberapa solusi bagi anak yang sudah terlanjur mengkonsumsi rokok diantara sebagai berikut, pola makan sehat yaitu dengan mengganti pola makan buruk dengan pola makan sehat (4 sehat 5 sempurna/karbohidrat, vitamin, protein,) karena kandungan nikotin dalam rokok dapat menimbulkan dampak mengurangi selera makan terhadap indera perasa, indari stress, olahraga, melakukan nicotine replacement therapy (NRT); dengan cara alternatif menghilangkan stress atau konsultasi dengan dokter melalui terapi yang efektif seperti tablet, permen karet, pelester dan semprotan pada mulut dan hidung, hindari pemicu (kebiasaan buruk, siap makan harus merokok), dan akupuntur.

\subsection{Pemberdayaan Keluarga dalam Perlindungan Anak Dari Penyalahgunaan Zat Adiktif pada Anak di Desa Bandar Labuhan Kecamatan Tanjung Morawa}

Tingginya angka penyalahgunaan narkoba di Sumatera Utara tentunya menimbulkan keresahan dari berbagai pihak. Dalam hal ini juga termasuk penyalahgunaan zat adiktif oleh anak. Cengkraman zat berbahaya ini bukan hanya mengancam kesehatan penggunanya saja, akan tetapi juga orang-orang yang berada di sekitarnya.

Perlindungan anak terhadap zat adiktif ini merupakan amanat dari Pasal 59 Undang-Undang No. 35 Tahun 2014 tentang Perubahan Atas Undang-Undang No. 23 Tahun 2002 tentang Perlindungan Anak juga menyebutkan bahwa:

(1) Pemerintah, Pemerintah Daerah, dan lembaga negara lainnya berkewajiban dan bertanggung jawab untuk memberikan Perlindungan Khusus kepada Anak.

(2) Perlindungan Khusus kepada Anak sebagaimana dimaksud pada ayat (1) diberikan kepada:

a. Anak dalam situasi darurat;

b. Anak yang berhadapan dengan hukum;

c. Anak dari kelompok minoritas dan terisolasi;

d. Anak yang dieksploitasi secara ekonomi dan/atau seksual;

e. Anak yang menjadi korban penyalahgunaan narkotika, alkohol, psikotropika, dan zat adiktif lainnya;

f. Anak yang menjadi korban pornografi;

g. Anak dengan HIV/AIDS;

h. Anak korban penculikan, penjualan, dan/atau perdagangan;

i. Anak korban Kekerasan fisik dan/atau psikis;

j. Anak korban kejahatan seksual;

k. Anak korban jaringan terorisme;

1. Anak Penyandang Disabilitas;

m. Anak korban perlakuan salah dan penelantaran;

n. Anak dengan perilaku sosial menyimpang; dan

o. Anak yang menjadi korban stigmatisasi dari pelabelan terkait dengan kondisi Orang Tuanya.

Dari kutipan Pasal 59 Undang-Undang Perlindungan Anak jelas disebutkan pada Ayat 2 huruf e bahwa perlindungan khusus yang wajib diberikan oleh pemerintah, pemerintah daerah dan lembaga negara lain kepada anak yang menjadi korban penyalahgunaan narkotika, alkohol, psikotropika, dan zat adiktif lainnya.

Oleh karena itu, Provinsi Sumatera Utara mengeluarkan sebuah Peraturan Daerah Sumatera Utara No. 1 Tahun 2019 tentang Fasilitasi Pencegahan Penyalahgunaan Narkotika, Psikotropika dan Zat Adiktif Lainnya. Dalam Peraturan Daerah di dalam Bab III tentang Fasilitasi Pencegahan pada Pasal 8 disebutkan bahwa:

(1) Badan melaksanakan kegiatan fasilitasi pencegahan penyalahgunaan narkotika, psikotropika, dan zat adiktif lainnya; 
(2) Upaya fasilitasi pencegahan narkotika, psikotropika, dan zat adiktif lainnya sebagaimana dimaksud pada ayat (1) meliputi a. seminar; b. lokakarya; c. workshop; d. halaqoh; e. pagelaran, festival seni dan budaya; f. outbond seperti jamboree, perkemahan, dan napak tilas; g. perlombaan seperti lomba pidato, jalan sehat, cipta lagu; h. pemberdayaan masyarakat; i. pelatihan masyarakat; j. karya tulis ilmiah dan k. sosialisasi, diseminasi, asistensi dan bimbingan teknis.

(3) Upaya fasilitasi pencegahan penyalahgunaan narkotika, psikotropika, dan zat adiktif lainnya sebagaimana yang dimaksud pada ayat (2) dilaksanakan melalui:

a. keluarga; b. lingkungan masyarakat; c. satuan pendidikan; d.organisasi kemasyarakatan; e.badan usaha, tempat usaha, hotel/penginapan, pemondokan/asrama dan tempat hiburan; $\mathrm{f}$. lembaga pemerintahan dan DPRD; g. media massa; h. komunitas; i. lembaga adat di daerah. Pada Bagian Kedua mengenai Fasilitas Pencegahan Berbasis keluarga di dalam Pasal 9 disebutkan:

Tugas orang tua dalam upaya pencegahan penyalahgunaan narkotika, psikotropika, dan zat adiktif lainnya, antara lain:

a. Memberikan pendidikan keagamaan;

b. Meningkatkan komunikasi dengan anggota keluarga, khususnya dengan anak;

c. Melakukan pendampingan kepada anggota keluarga agar mempunyai kekuatan mental dan keberanian untuk menolak penyalahgunaan NAPZA; dan

d. Memberikan edukasi dan informasi yang benar kepada anggota keluarga mengenai bahaya penyalahgunaan NAPZA.

Selain terdapat upaya fasilitasi pencegahan, di dalam Peraturan Daerah Sumatera Utara No.

1 Tahun 2019 tentang Fasilitasi Pencegahan Penyalahgunaan Narkotika, Psikotropika dan Zat Adiktif Lainnya juga terdapat Upaya Khusus sebagaimana diatur pada Bab IV Pasal 26. Upaya khusus ini juga mengatur tentang penyalahgunaan narkotika, psikotropika, dan zat adiktif lainnya pada anak. Pasal 26 menyebutkan bahwa:

(1). Upaya khusus adalah upaya perlindungan Upaya khusus adalah upaya perlindungan khusus terhadap anak-anakselaku pecandu, penyalahguna dan korban penyalahgunaan Narkotika, Psikotropika dan Zat Adiktif Lainnyasebagaimana dimaksud dalam ketentuan perundangundangan.

(2). Upaya khusus sebagaimana dimaksud pada ayat (1) berupa:a.pendampingan; dan b.advokasi.

(3). Pendampingan sebagaimana dimaksud pada ayat (2) huruf a diberikan kepada: a.pecandu Narkotika, Psikotropika dan Zat Adiktif Lainnya yang belum cukup umur, yang terindikasi menggunakan NAPZAmelalui test urine dan/atau tes darah (blood test); b.pecandu Narkotika, Psikotropika dan Zat Adiktif Lainnya yang belum cukup umur, yang tertangkap tangan membawa NAPZAyang tidak melebihi ketentuan peraturan perundang-undangan; dan/atau c.pecandu Narkotika, Psikotropika dan Zat Adiktif Lainnya yang sudah cukup umur yang melaporkan diri atau dilaporkan keluarganya.

(4). Advokasi sebagaimana dimaksud pada ayat (2) huruf b diberikan kepada: a.pecandu Narkotika, Psikotropika dan Zat Adiktif Lainnya yang belum cukup umur, yang terindikasi menggunakan NAPZAmelalui test urine dan/atau tes darah (blood test); b.pecandu Narkotika, Psikotropika dan Zat Adiktif Lainnya yang belum cukup umur, yang tertangkap tangan membawa NAPZAyang tidak melebihi ketentuan peraturan perundang-undangan; dan/atau c.pecandu Narkotika, Psikotropika dan Zat Adiktif Lainnya yang sudah cukup umur yang melaporkan diri atau dilaporkan keluarganya; dan/atau d.keluarga dari Pecandu Narkotika, Psikotropika dan Zat Adiktif Lainnya sebagaimana dimaksud dalam huruf a, huruf $\mathrm{b}$ dan huruf $\mathrm{c}$.

(5). Pelaksanaan Pendampingan dan Advokasi sebagaimana dimaksud pada ayat (3) dan ayat (4) akan diatur lebih lanjut dengan Peraturan Gubernur. 


\section{KESIMPULAN (CONCLUSION)}

Berdasarkan hasil pelaksanaan Pengabdian Kepada Masyarakat ini, maka terdapat tiga hal yang dapat ditarik sebagai kesimpulan yaitu:

a. Kondisi penyalahgunaan zat adiktif pada anak di Desa Bandar Labuhan Kecamatan Tanjung Morawa sebagaian besar anak mengkonsumsi rokok, lem dan bensin. Sebagian besar anak dan remaja biasanya mengkonsumsi zat adiktif ini secara sembunyi-sembunyi, selebihnya dilakukan secara terbuka. Dari informasi yang didapat dari peserta pengabdian, sebagian besar masyarakat sudah memberi teguran, nasihat, edukasi sampai memberi kata-kata sindiran kepada anak yang mengkonsumsi zat adiktif.

b. Faktor-faktor yang menyebabkan anak menyalahgunakan zat adiktif di Desa Bandar Labuhan Kecamatan Tanjung Morawa, antara lain, pergaulan dengan teman sebaya yang merupakan perokok atau pengguna zat adiktif, ajang coba-coba, rasa penasaran yang tinggi, kurang mendapat perhatian dari orang tua, kurangnya keterbukaan dan minimnya informasi tentang zat adiktif di dalam keluarga dan lingkungan yang kurang peduli terhadap anak.

c. Perlindungan anak terhadap zat adiktif ini merupakan amanat dari Undang-Undang No. 35 Tahun 2014 tentang Perubahan Atas Undang-Undang No. 23 Tahun 2002 tentang Perlindungan Anak Pasal 59 menyebutkan bahwa Pemerintah, Pemerintah Daerah, dan lembaga negara lainnya berkewajiban dan bertanggung jawab untuk memberikan Perlindungan Khusus kepada Anak dan Perlindungan Khusus kepada Anak salah satunya diberikan kepada Anak yang menjadi korban penyalahgunaan narkotika, alkohol, psikotropika, dan zat adiktif lainnya. Selain itu, Provinsi Sumatera Utara mengeluarkan sebuah Peraturan Daerah Sumatera Utara No. 1 Tahun 2019 tentang Fasilitasi Pencegahan Penyalahgunaan Narkotika, Psikotropika dan Zat Adiktif Lainnya. Dalam Peraturan Daerah di dalam Bab III tentang Fasilitasi Pencegahan salah satunya adalah melalui keluarga. Tugas orang tua dalam upaya pencegahan penyalahgunaan NAPZA, antara lain, memberikan pendidikan keagamaan, meningkatkan komunikasi dengan anggota keluarga, khususnya dengan anak, melakukan pendampingan kepada anggota keluarga agar mempunyai kekuatan mental dan keberanian untuk menolak penyalahgunaan NAPZA dan memberikan edukasi dan informasi yang benar kepada anggota keluarga mengenai bahaya penyalahgunaan NAPZA.

\section{UCAPAN TERIMAKASIH (ACKNOWLEDGMENTS)}

Artikel ini merupakan luaran wajib dari Program Pengabdian Kepada Masyarakat Skema Dosen Wajib Mengabdi yang dibiayai oleh danan NON PNBP Universitas Sumatera Utara. Oleh karena itu, diucapkan terima kasih kepada Rektor Universitas Sumatera Utara atas dukungan dana dan fasilitas yang diberikan. Ucapan terima kasih juga disampaikan kepada Mitra yang membantu terlaksananya kegiatan pengabdian kepada masyarakat ini.

\section{DAFTAR PUSTAKA (REFERENCES)}

Afdol Rahmadi, Yuniar Lestari, Yenita, Hubungan Pengetahuan dan Sikap Terhadap Rokok Dengan Kebiasaan Merokok Siswa SMP di Kota Padang. Jurnal Kesehatan Andalas, Vol 2 No. 1 (2013), hlm. 25-28

C.S.T. Kansil, Engelien R. Palandeng, dan Altje Agustin Musa, Tindak Pidana Dalam UndangUndang Nasional, Jakarta: Jala Permata Aksara, (2009) 
Eva Syahfitri Nasution et.al. Family empowerment in protecting children

Harbia, Muhammad Multazam, Andi Asrina, Dampak Penyalahgunaan Narkotika, Psikotropika, dan Zat Adiktif lainnya (NAPZA) terhadap perilaku seks pra nikah Window of Health: Jurnal Kesehatan, Vol. 1 No. 3, Juli (2018), hlm. 204-2016

Ratna Umi Nurlila dan Jumarddin La Fua, Penyalahgunaan Zat Adiktif Pada Siswa Kelas VOOO di Sekolah Menengah Pertama Negeri 05 Kota Kendari, Jurnal AL-Ta'dib, Vol 10 No. 1 Januari- Juni (2017), hlm. 70-90

Solina, Triana Arisdiani, Yuni Puji Widyastuti, Hubungan Peran Orang Tua dengan Perilaku Konsumsi Minuman Alkohol Pada Remaja Laki-laki, Jurnal Keperawatan Jiwa, Vol. 6 No. 1, Mei (2018), hlm. 36-45.

Undang-Undang No. 35 Tahun 2014 tentang Perubahan Atas Undang-Undang No. 23 Tahun 2002 tentang Perlindungan Anak, Bandung: Fokus Media, 2010

Peraturan Daerah Sumatera Utara No. 1 Tahun 2019 tentang Fasilitasi Pencegahan Penyalahgunaan Narkotika, Psikotropika dan Zat Adiktif Lainnya. 